WCH-447

Rev. 0

River Corridor Closure Contract

\title{
300 Area D4 Project Fiscal Year 2010 Building Completion Report
}

\section{January 2011}

For Public Release

\section{Washington Closure Hanford}


TRADEMARK DISCLAIMER

Reference herein to any specific commercial product, process, or service by trade name, trademark, manufacturer, or otherwise, does not necessarily constitute or imply its endorsement, recommendation, or favoring by the United States Government or any agency thereof or its contractors or subcontractors.

This report has been reproduced from the best available copy.

Printed in the United States of America 


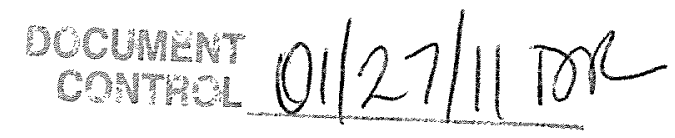

WCH-447

Rev. 0

\section{STANDARD APPROVAL PAGE}

Title:

300 Area D4 Project Fiscal Year 2010 Building Completion Report

Author Name: B. J. Skwarek

Approval: $\quad$ L. M. Douglas, Project Engineer

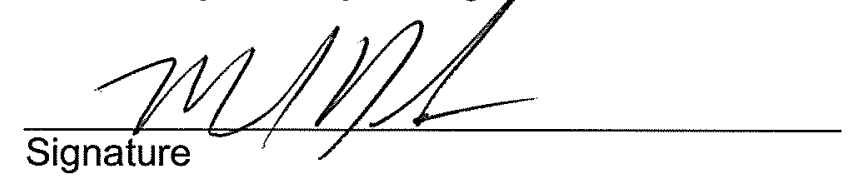

$\frac{1-18-11}{\text { Date }}$

The approval signature on this page indicates that this document has been authorized for information release to the public through appropriate channels. No other forms or signatures are required to document this information release. 


\title{
River Corridor Closure Contract
}

\section{Area D4 Project Fiscal Year 2010 Building Completion Report}

\author{
January 2011
}

\author{
Author: \\ B. J. Skwarek \\ WorleyParsons Polestar
}

For Public Release 


\section{TABLE OF CONTENTS}

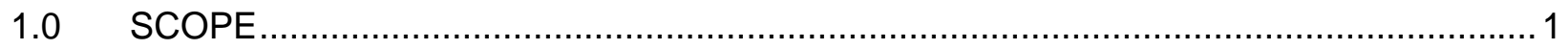

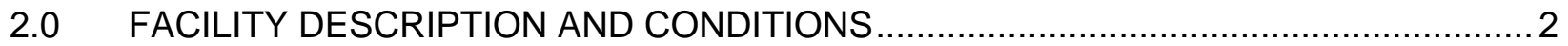

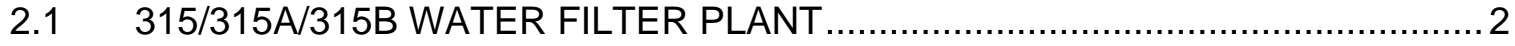

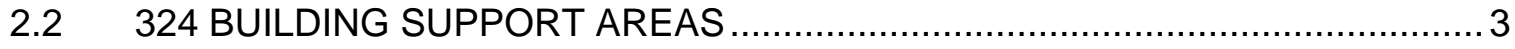

$2.3 \quad 327$ POST-IRRADIATION TEST FACILITY ............................................ 4

2.4336 CORE SEGMENT DEVELOPMENT FACILITY ............................... 5

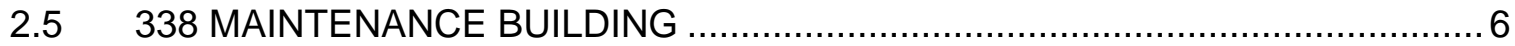

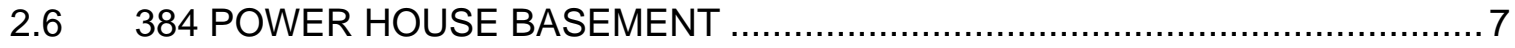

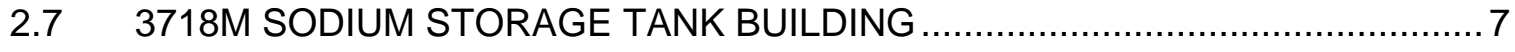

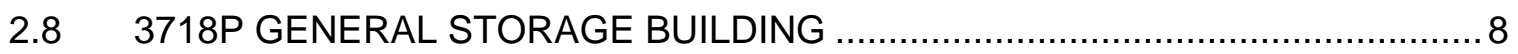

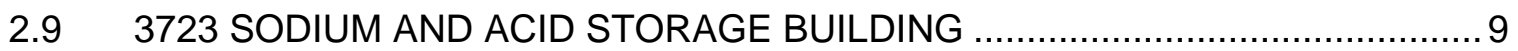

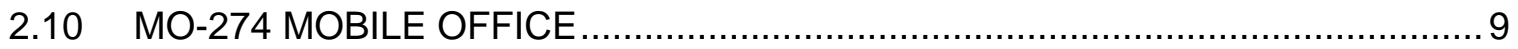

2.11 MO-275 MOBILE BUILDING .............................................................. 10

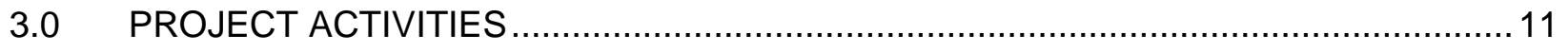

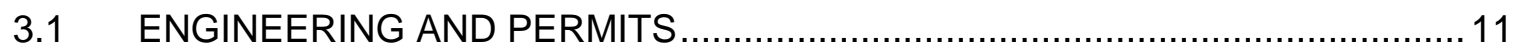

3.2 HAZARDOUS MATERIAL REMOVAL .................................................. 12

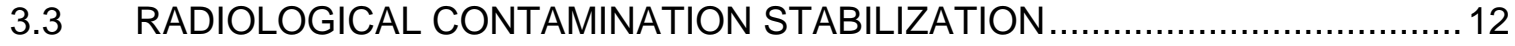

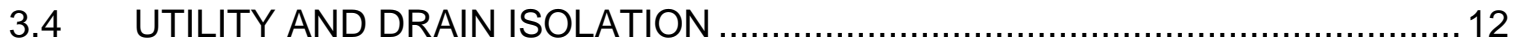

3.5 DEMOLITION OF ABOVE-GRADE STRUCTURES …............................... 12

3.6 BELOW-GRADE DEMOLITION AND SITE RESTORATION.......................... 13

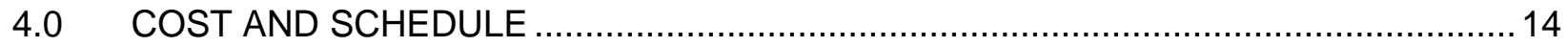

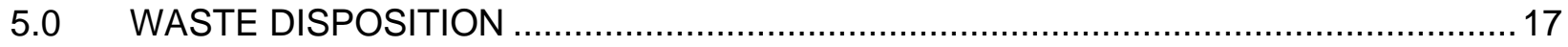

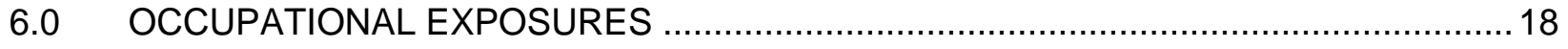

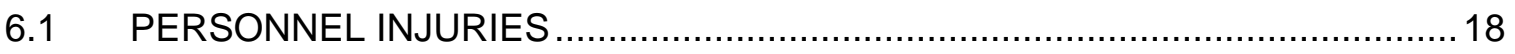

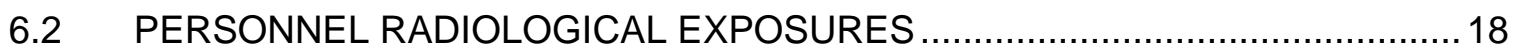

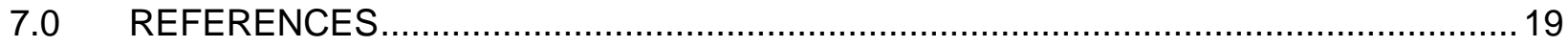




\section{FIGURES}

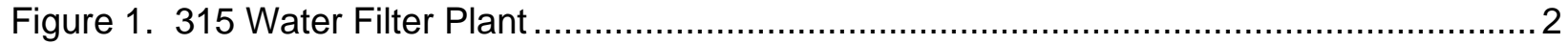

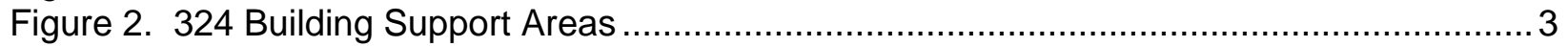

Figure 3. 327 Post-Irradiation Test Facility ................................................................... 4

Figure 4. 336 Core Segment Development Facility ….................................................. 5

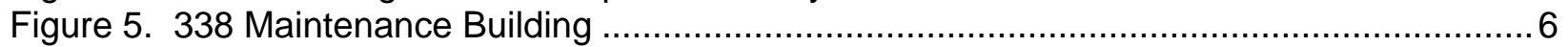

Figure 6. 384 Power House Basement ...................................................................... 7

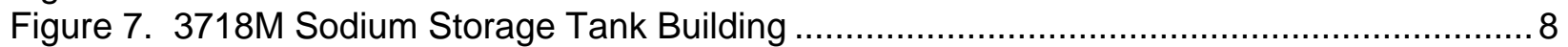

Figure 8. 3718P General Storage Building .................................................................. 8

Figure 9. 3723 Sodium and Acid Storage Building ...................................................... 9

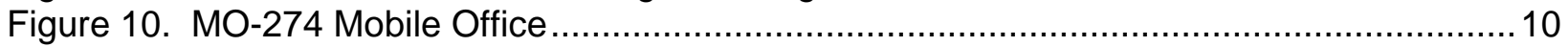

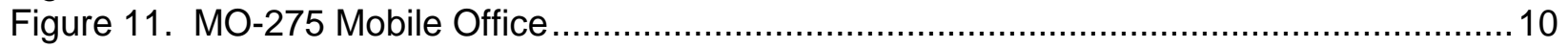

\section{TABLES}

Table 1. Plant Forces Work Reviews. ...................................................................... 11

Table 2. Hazard Categorization Evaluations and Results............................................... 11

Table 3. Facility As-Left Condition Summary................................................................. 13

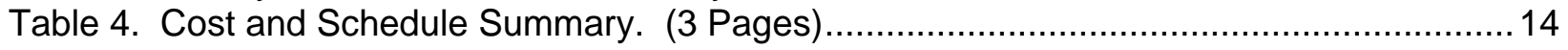

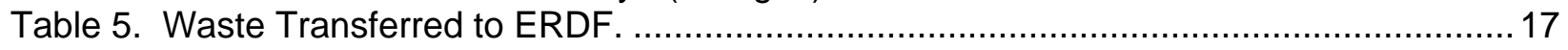




\section{METRIC CONVERSION CHART}

\begin{tabular}{|c|c|c|c|c|c|}
\hline \multicolumn{3}{|c|}{ Into Metric Units } & \multicolumn{3}{|c|}{ Out of Metric Units } \\
\hline If You Know & Multiply By & To Get & If You Know & Multiply By & To Get \\
\hline Length & & & Length & & \\
\hline inches & 25.4 & millimeters & millimeters & 0.039 & inches \\
\hline inches & 2.54 & centimeters & centimeters & 0.394 & inches \\
\hline feet & 0.305 & meters & meters & 3.281 & feet \\
\hline yards & 0.914 & meters & meters & 1.094 & yards \\
\hline miles & 1.609 & kilometers & kilometers & 0.621 & miles \\
\hline Area & & & Area & & \\
\hline Sq. inches & 6.452 & sq. centimeters & sq. centimeters & 0.155 & sq. inches \\
\hline sq. feet & 0.093 & sq. meters & sq. meters & 10.76 & sq. feet \\
\hline sq. yards & 0.836 & sq. meters & sq. meters & 1.196 & sq. yards \\
\hline sq. miles & 2.6 & sq. kilometers & sq. kilometers & 0.4 & sq. miles \\
\hline acres & 0.405 & hectares & hectares & 2.47 & acres \\
\hline Mass (weight) & & & Mass (weight) & & \\
\hline ounces & 28.35 & grams & grams & 0.035 & ounces \\
\hline pounds & 0.454 & kilograms & kilograms & 2.205 & pounds \\
\hline Ton & 0.907 & metric ton & metric ton & 1.102 & ton \\
\hline Volume & & & Volume & & \\
\hline teaspoons & 5 & milliliters & milliliters & 0.033 & fluid ounces \\
\hline tablespoons & 15 & milliliters & liters & 2.1 & pints \\
\hline fluid ounces & 30 & milliliters & liters & 1.057 & quarts \\
\hline cups & 0.24 & liters & liters & 0.264 & gallons \\
\hline pints & 0.47 & liters & cubic meters & 35.315 & cubic feet \\
\hline quarts & 0.95 & liters & cubic meters & 1.308 & cubic yards \\
\hline gallons & 3.8 & liters & & & \\
\hline cubic feet & 0.028 & cubic meters & & & \\
\hline cubic yards & 0.765 & cubic meters & & & \\
\hline Temperature & & & Temperature & & \\
\hline Fahrenheit & $\begin{array}{l}\text { subtract } 32 \text {, } \\
\text { then } \\
\text { multiply by } \\
5 / 9\end{array}$ & Celsius & Celsius & $\begin{array}{l}\text { multiply by } \\
9 / 5, \text { then } \\
\text { add } 32\end{array}$ & Fahrenheit \\
\hline $\begin{array}{l}\text { Radioactivity } \\
\text { picocuries }\end{array}$ & 37 & millibecquerel & $\begin{array}{l}\text { Radioactivity } \\
\text { millibecquerels }\end{array}$ & 0.027 & picocuries \\
\hline
\end{tabular}




\subsection{SCOPE}

This report summarizes the deactivation, decontamination, decommissioning, and demolition (D4) activities of facilities in the 300 Area of the Hanford Site in fiscal year (FY) 2010. These facilities include:

1. 315 Water Treatment Plant (315, 315A, 315B)

2. 324 Building Support Areas (new office addition, High-Bay Engineering Laboratory, maintenance shop, and 324C Experimental Lithium Enclosure)

3. 327 Post-Irradiation Test Facility (above-grade)

4. 336 Core Segment Development Facility (above-grade)

5. 338 Maintenance Building (above-grade)

6. 384 Power House basement

7. 3718M Sodium Storage Tank Building (below-grade)

8. 3718P General Storage Building (above-grade)

9. 3723 Solvent and Acid Storage Building (above-grade)

10. MO-274 Mobile Office

11. MO-275 Mobile Office

The D4 of these facilities included characterization; engineering; removal of hazardous materials; removal or stabilization of radiologically contaminated materials; equipment removal; utility disconnection; deactivation, decontamination, demolition of the structure; and stabilization (in-place) or removal of slabs and foundations.

Two significant below-grade structures were removed by D4 in FY2010 and are discussed in this report (384 basement and 3718M). On- or below-grade slabs removed in FY2010 of buildings demolished in previous fiscal years were removed by either the D4 Closure Project or the Field Remediation Closure Project and are listed in Table 5.0.

As reference, previous D4 Building Completion Reports are:

WCH-41 (FY06, $1^{\text {st }}$ Quarter)

WCH-94 (FY06, $2^{\text {nd }}$ Quarter)

WCH-116 (FY06, $3^{\text {rd }}$ Quarter)

WCH-143 (FY06, $4^{\text {th }}$ Quarter)

WCH-309 (FY07)

WCH-310 (FY08)

WCH-374 (FY09) 


\subsection{FACILITY DESCRIPTION AND CONDITIONS}

The buildings detailed in this report were located in the 300 Area of the Hanford Site, which is owned and operated by the U.S. Department of Energy (DOE), in Benton County, Washington. The 300 Area was constructed and operated as a reactor fuel fabrication and laboratory complex.

\section{$2.1315 / 315 A / 315 B$ WATER FILTER PLANT}

The 315 Water Filter Plant (315, 315A and 315B) was located on the north side of Locust Street in the southeast 300 Area about 370 feet west of the Columbia River. The facility originally supplied filtered cooling water to the 309 Plutonium Recycle Test Reactor, but was later modified to supply sanitary water for the entire 300 Area. Operation was discontinued in the mid 1990's when the 300 Area began receiving sanitary water from the City of Richland. The facility was transitioned to the WCH contract in August 2005.

Figure 1. 315 Water Filter Plant

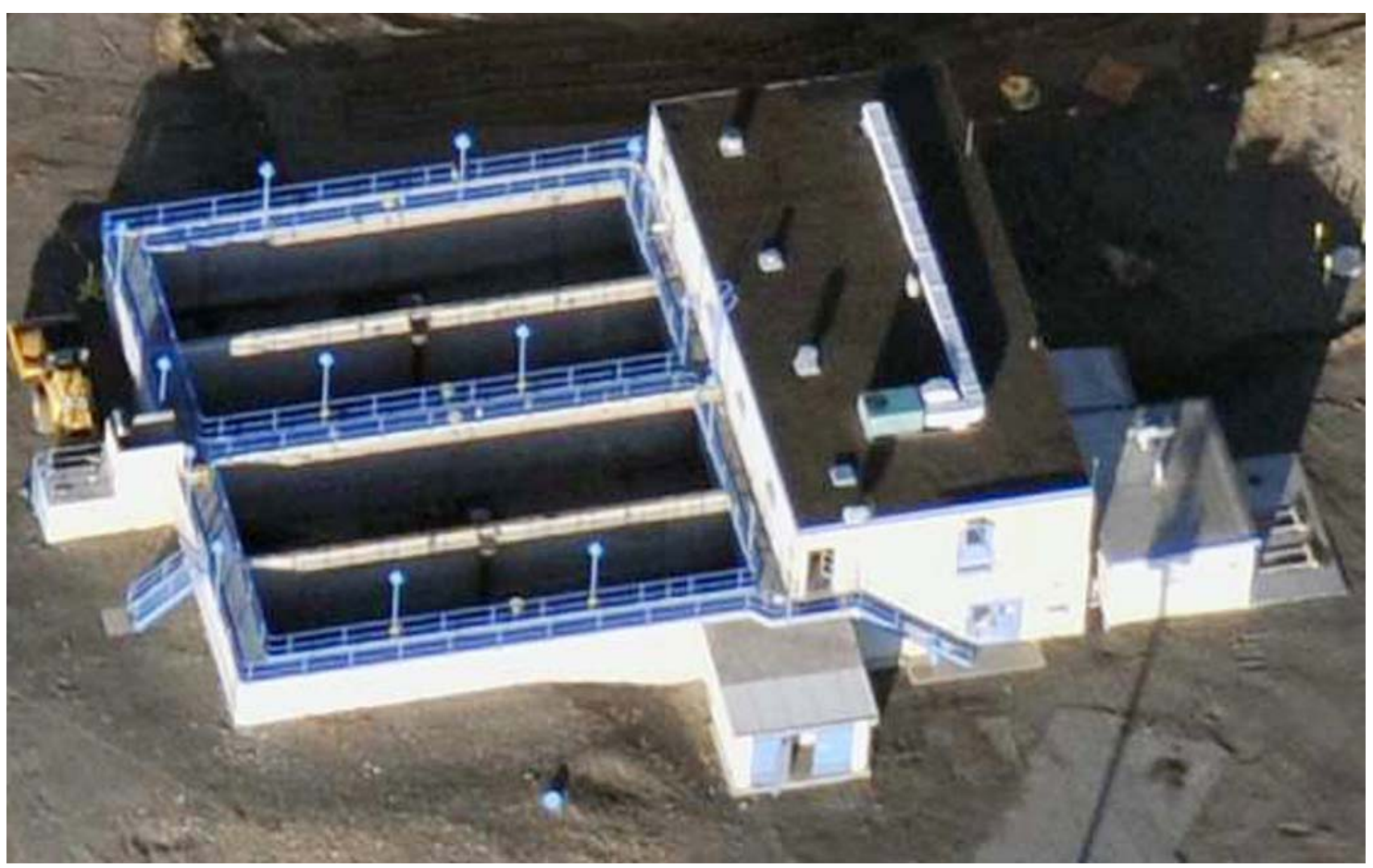

The 315 Water Filter Plant was a $65 \mathrm{ft}$ by $94 \mathrm{ft}$ structure constructed of reinforced concrete and concrete block. The facility included the main 315 Building and two annexed concrete/concrete block structures: the 315A Transformer House located on the eastside of the 315 Building, and the 315B Chlorine Storage Facility located on the northeast corner of the 315 Building. The 315 Building had four clearwell sedimentation basins, four troughs, filter bank, alum storage tank (5600 gallons, estimated), small tanks, several pumps, motors and an extensive piping system. The 315B Building stored two, one-ton chlorine supply cylinders. 


\section{$2.2 \quad 324$ BUILDING SUPPORT AREAS}

The 324 Building, known as the Engineering Development Laboratory, was completed in 1965. Four significant support areas were added to the building since its original construction: a new office addition, a High-Bay Engineering Laboratory, a maintenance/machining shop, and the 324C Experimental Lithium Enclosure. The 324 Complex was operated by Pacific Northwest National Laboratory (PNNL) until 1996, when the facility was transferred to B\&W Hanford Company (BWHC) for interim operation and eventual stabilization and deactivation in preparation for building decommissioning. PNNL continued limited operations in the 324 Complex until October 1998. Responsibility for the building stabilization and deactivation was assumed by Fluor Hanford (FH) in September 1999 and then by Washington Closure Hanford (WCH) in August 2005. In FY2010, WCH demolished only the four support areas to the 324 Building. These areas did not contain any radiological contamination or chemical inventory.

Figure 2. 324 Building Support Areas

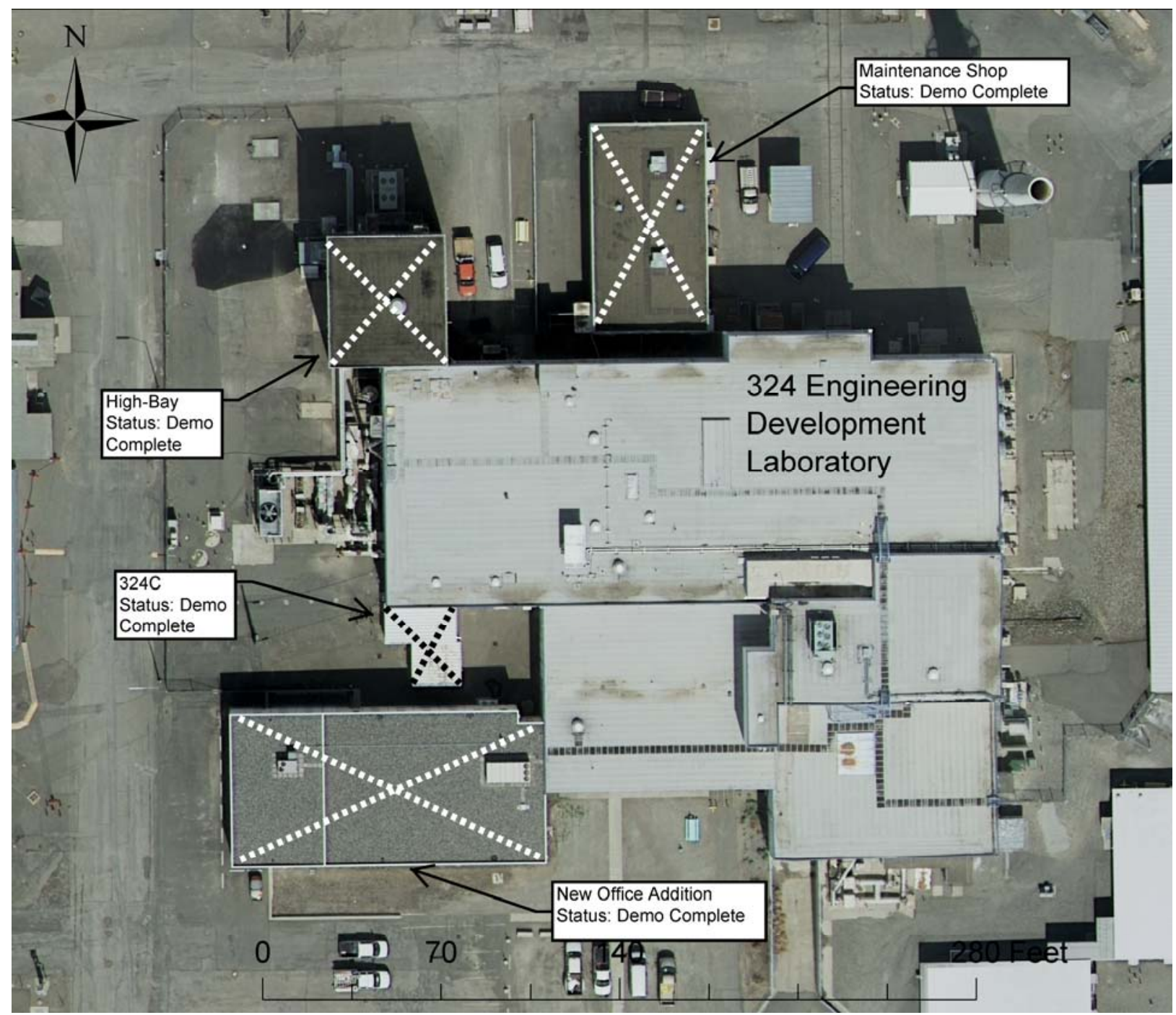


The new office building ( $60 \mathrm{ft}$ by $86 \mathrm{ft}$ ) was a two-story tilt-up concrete panel structure on a slab with built-up tar and gravel roof. The High-Bay Engineering Laboratory ( $45 \mathrm{ft}$ by $50 \mathrm{ft}$ ), the maintenance shop ( $44 \mathrm{ft}$ by $100 \mathrm{ft}$ ), and the 324C Experimental Lithium Enclosure (18 ft by $34 \mathrm{ft}$ ) were steel frame on slab with fluted steel panel siding and built-up tar and gravel roofing.

\section{$2.3 \quad 327$ POST-IRRADIATION TEST FACILITY}

The 327 Facility performed its designed mission from 1953 to 1996 . Services historically performed in the 327 Building included physical and mechanical properties measurement and testing, metrology, metallography, ceramography, auto radiography, fission product gas extraction and sampling, microdrill sampling, sampling for burnup and chemical analysis, encapsulation and disassembly of irradiated test modules, and encapsulation of irradiated structural materials for further irradiation testing. Irradiated fuels examined consisted primarily of fuel pins containing plutonium oxides and uranium oxides. Other fuel forms such as metals, carbides, and nitrides were handled occasionally. Examination, testing, and processing operations were carried out in the shielded cells equipped with viewing windows, manipulators, and special equipment.

Figure 3. 327 Post-Irradiation Test Facility

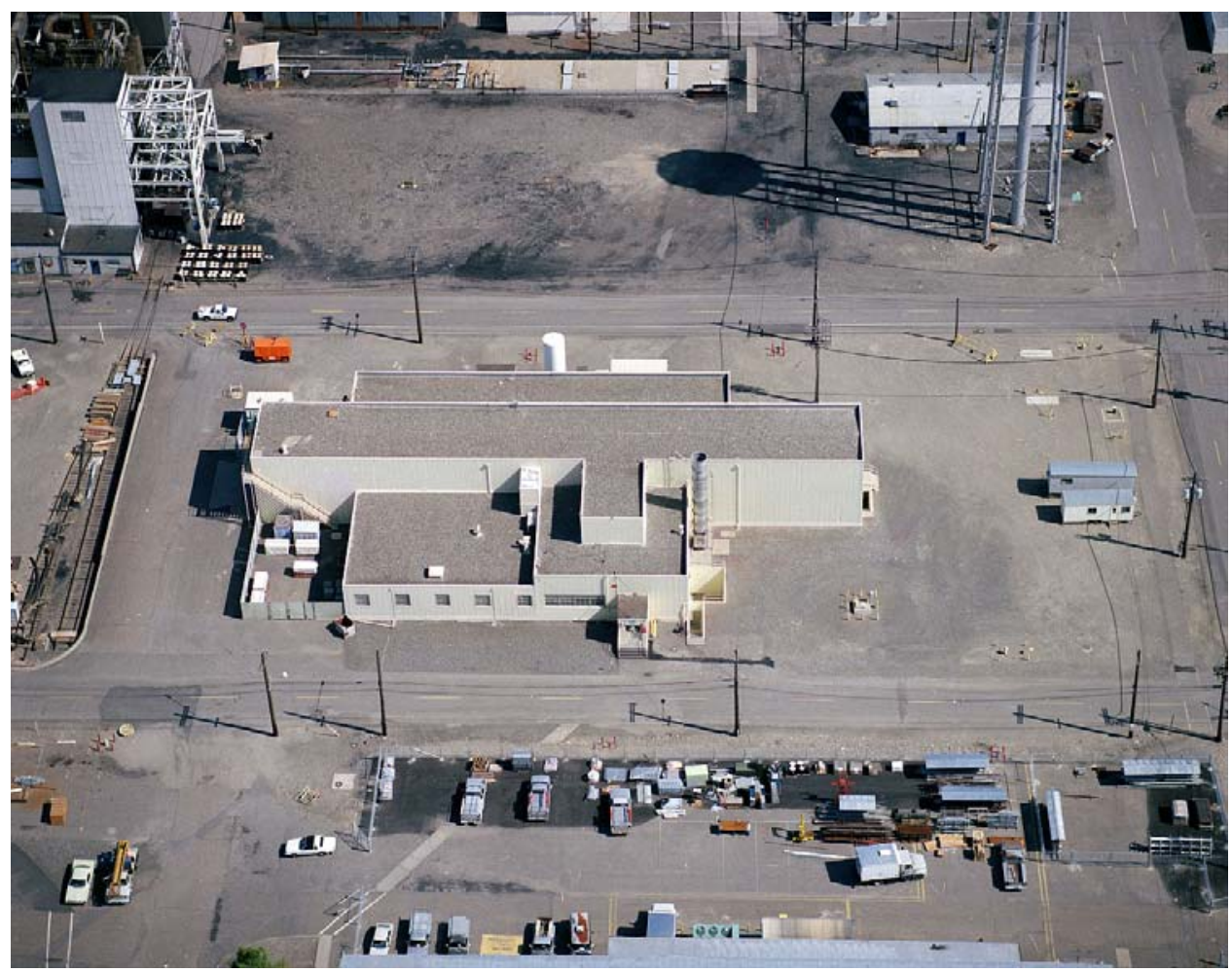

The 327 Building was a single-story structure with a welded steel framework with a partial basement. Maximum dimensions were $215 \mathrm{ft}$ by $140 \mathrm{ft}$ and $32 \mathrm{ft}$ in height. The total work area of the building was approximately $25,200 \mathrm{ft}^{2}$. The slightly sloped roof was a steel deck with a 20-year built-up of tar and gravel. Exterior walls were insulated fluted-steel panels. The first floor was reinforced concrete or steel decking covered with concrete. 
The 327 Complex was operated by Pacific Northwest National Laboratory (PNNL) until 1996, when the facility was transferred to B\&W Hanford Company (BWHC) for interim operation and eventual stabilization and deactivation in preparation for building decommissioning.

Responsibility for the building stabilization and deactivation was assumed by Fluor Hanford $(\mathrm{FH})$ in September 1999. Washington Closure Hanford (WCH) took possession in August 2005.

\section{$2.4 \quad 336$ CORE SEGMENT DEVELOPMENT FACILITY}

The 336 Building was located on Locust Street in the east side of the 300 Area. The building was originally constructed to house experimental equipment for the study of the properties of sodium. It was known as the Core Segment Development Facility and supported Fast Flux Test Facility (FFTF) developmental studies. WCH took possession of the facility in September 2008.

Figure 4. 336 Core Segment Development Facility

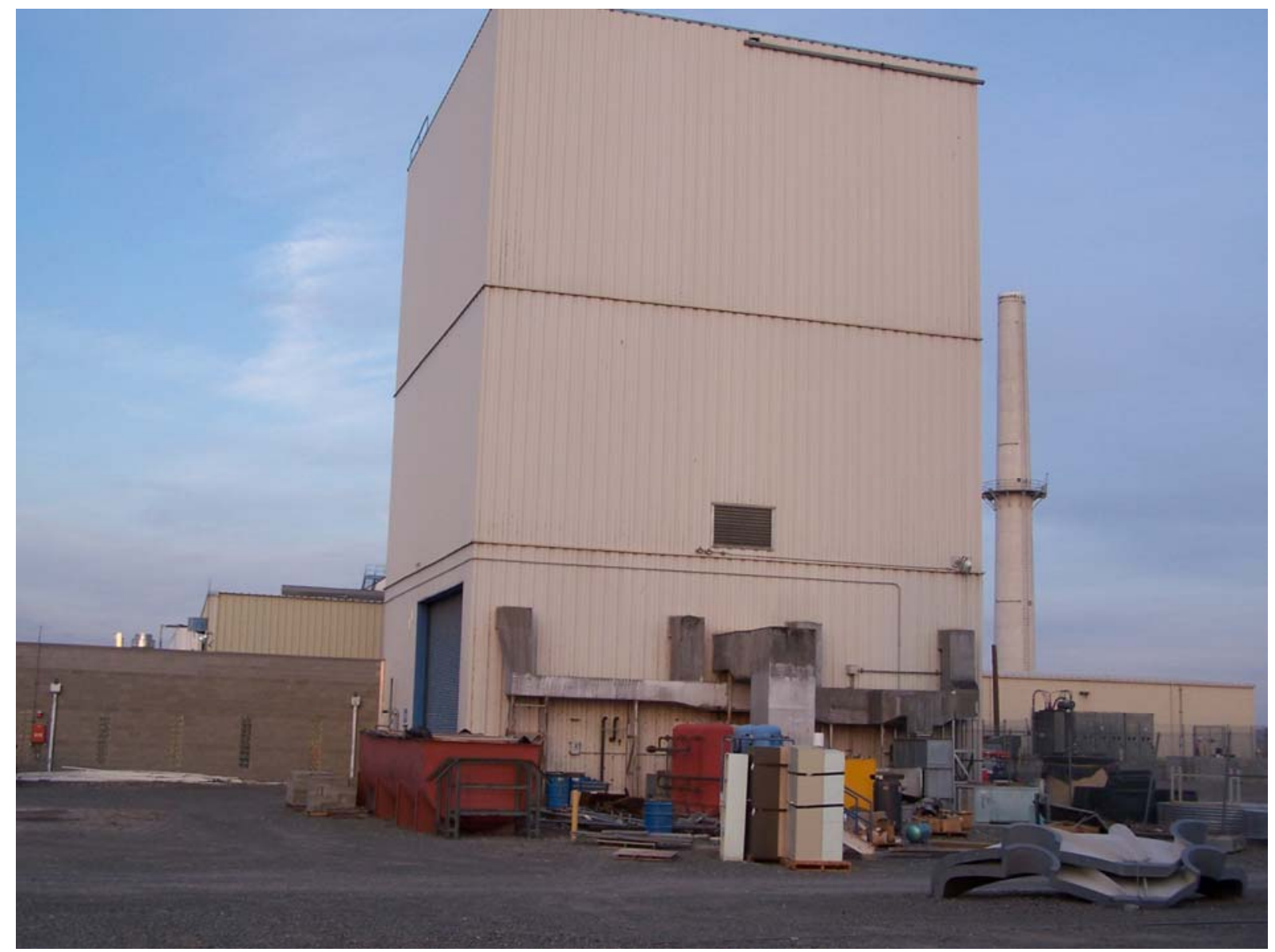

The 336 Building was constructed in 1969 on a concrete foundation with the dimensions of $50 \mathrm{ft}$ by $50 \mathrm{ft}$ by $65 \mathrm{ft}$ in height. It was a steel-framed structure with insulated steel corrugated siding and a corrugated steel roof topped with gravel. The building also contained a $50 \mathrm{ft}$ deep concrete lined pit which was located at the center of the high bay portion of the building with a truss-supported, steel-plate/grate floor cover. The pit had an approximately one-foot sump below the lowest level floor grates. The original structure contained a five-ton bridge crane, sodium storage vessel, argon supply tank, a computer room and various pieces of electronic 
control equipment. A wet chemistry laboratory addition was constructed (two wet laboratories, common area and restrooms) to the building, consisting of concrete masonry units containing steel-studded, gypsum board-covered interior walls and vinyl ceiling tiles.

\subsection{MAINTENANCE BUILDING}

The 338 Building was originally located in 100-F Area, but was relocated in the eastern portion of the 300 area in 1971. The building was last known as the Maintenance Building and served as a less-than-90-day storage facility for hazardous materials. The building was turned over to WCH for demolition in October 2008.

Figure 5. 338 Maintenance Building

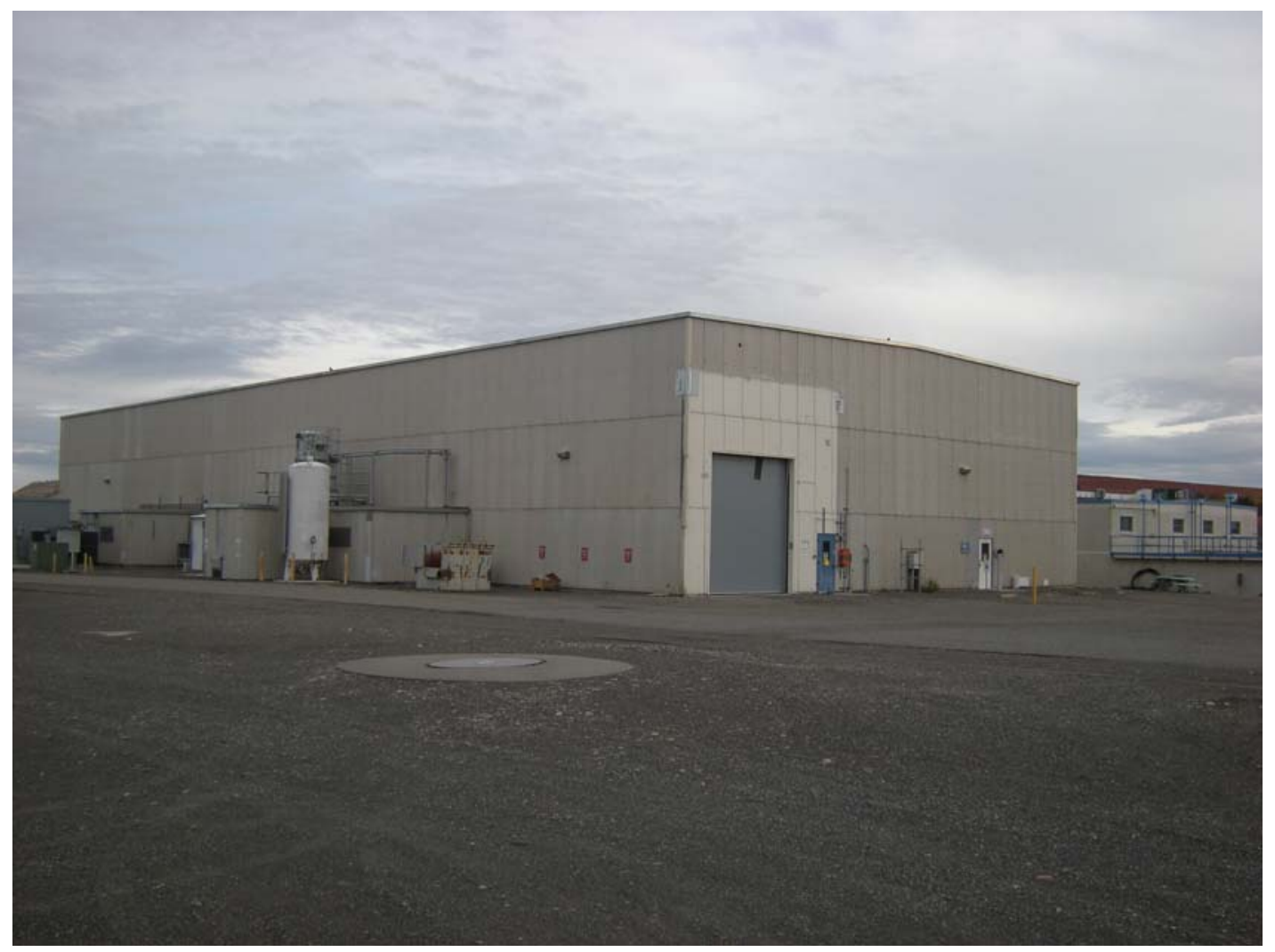

The 338 Building was a single-story bolted steel frame structure originally used in the 300 Area to provide space to receive, mock up, test and store components and certified materials for use in the High Temperature Sodium Facility. The structure, $80 \mathrm{ft}$ by $196 \mathrm{ft}$ by $30 \mathrm{ft}$, was constructed of corrugated transite (steel and asbestos) siding. The slightly sloped roof had a built-up asphalt and gravel finish, and the main floor was painted concrete. Interior walls were constructed of metal studs covered with gypsum board siding. The structure included a pit (50 ft by $65 \mathrm{ft}$ by $33 \mathrm{ft}$ ) in the north end, covered by a truss-supported steel plate. A sump ( $20 \mathrm{ft}$ by $12 \mathrm{ft}$ by $4 \mathrm{ft}$ ) was located in the south end of the pit. A 20-ton bridge crane served the building's entire interior floor space. Four attached cubicles were added on the east and west outer walls to provide space for heat pumps. An additional cubicle housing change rooms and sanitary restrooms were added on the east side, and an entry air lock to provide a barrier against 
blowing dirt and dust was placed on the south end. These additions brought the building's total area to $20,869 \mathrm{sq} \mathrm{ft}$.

\section{$2.6 \quad 384$ POWER HOUSE BASEMENT}

The 384 Building was known as the Power House and the Heating Plant. The building was constructed in 1943 to provide process and heating steam and compressed air to the 300 area. $\mathrm{WCH}$ took over responsibility for the building in 2005. Demolition of the above-grade structure was completed in May of 2008 (documented in Building Completion Report WCH-310).

Figure 6. 384 Power House Basement

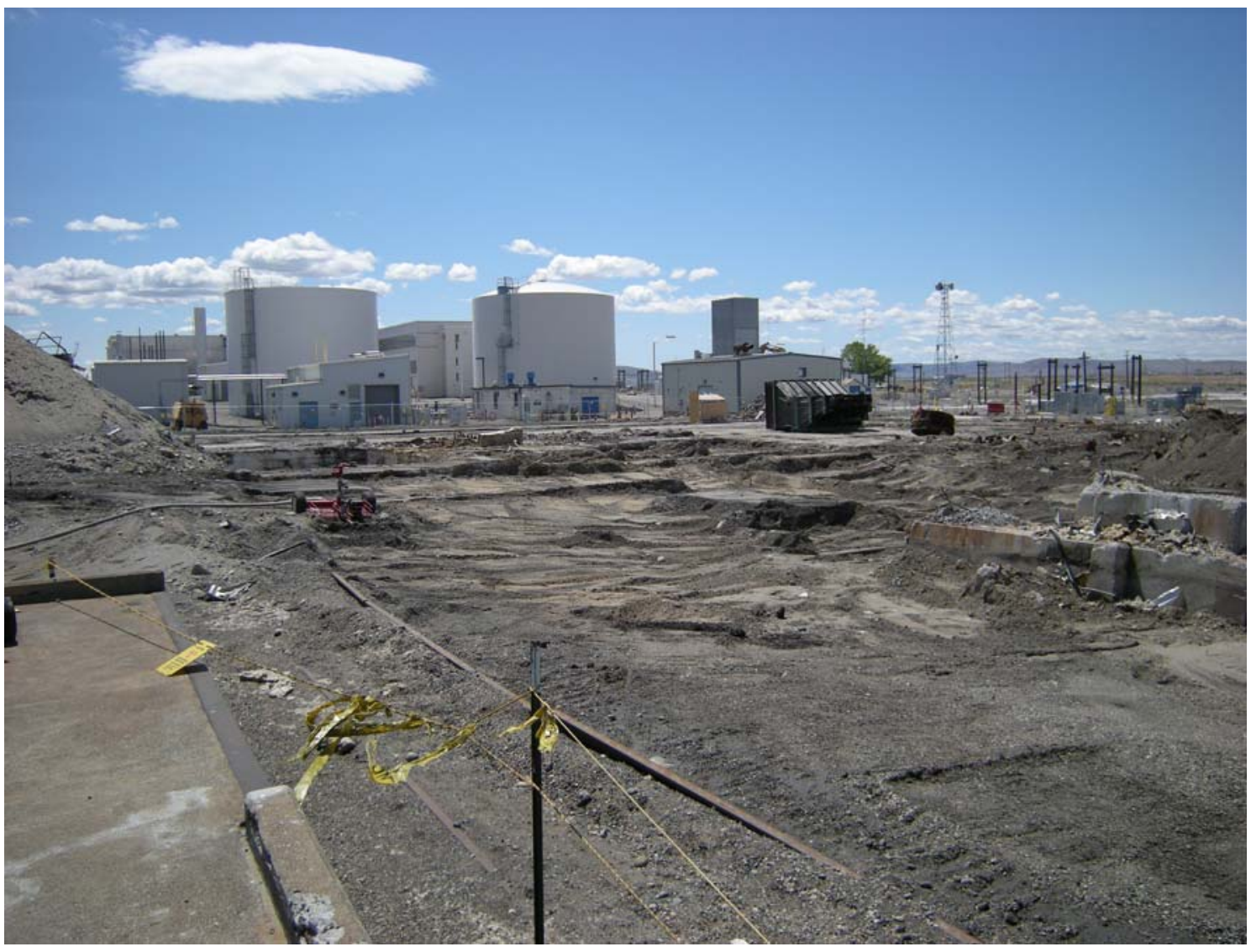

The dimensions of the 384 Building footprint during its last working configuration were $89 \mathrm{ft}$ by $208 \mathrm{ft}$. The basement contained coal transport equipment, ash removal equipment/structures, and condensate equipment. The foundation was reinforced concrete extending 4- to 5-feet below ground level and supported a 6 -inch reinforced concrete floor.

\section{$2.7 \quad 3718 M$ SODIUM STORAGE TANK BUILDING}

The 3718M Building (primarily below-grade) was known as the Sodium Storage Tank Building and was constructed in the early 1970's in support of the High Temperature Sodium Facility. WCH gained possession of the facility in September 2005. 
Figure 7. 3718M Sodium Storage Tank Building

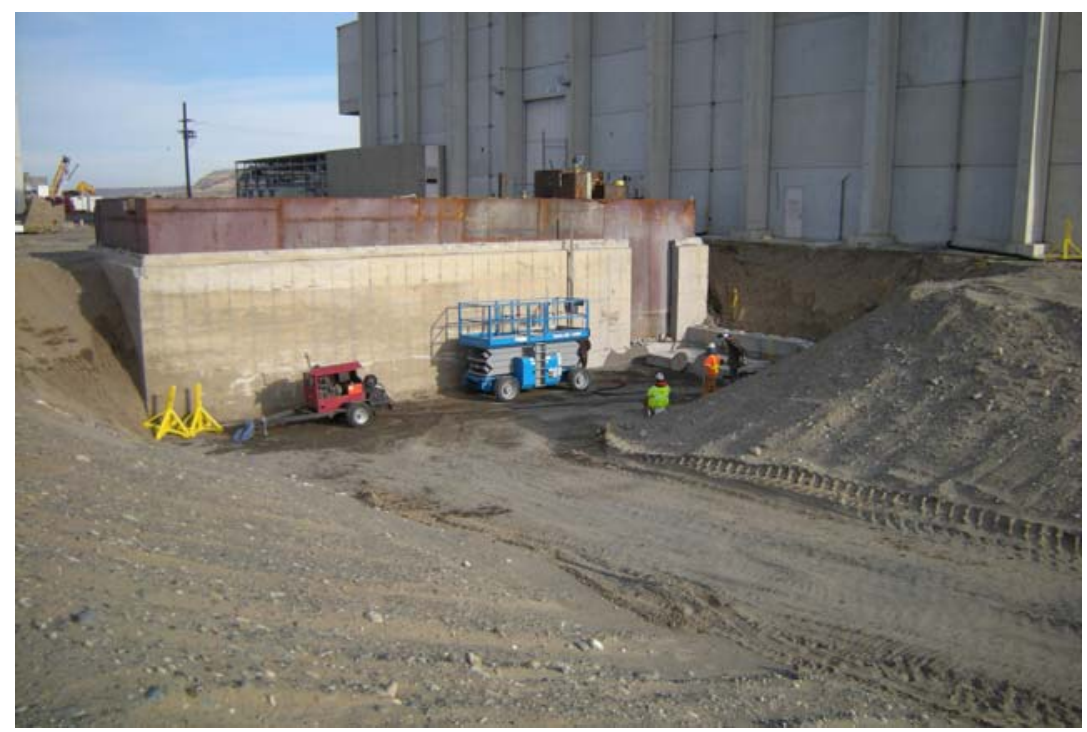

The $3718 \mathrm{M}$ Building was approximately $90 \mathrm{ft}$ by $23 \mathrm{ft}$ by $27 \mathrm{ft}$. Of the $27 \mathrm{ft}, 14.5 \mathrm{ft}$ was belowgrade. The building was set on a foundation that had $1.25 \mathrm{ft}$ thick walls and $1.5 \mathrm{ft}$ floor, all composed of reinforced concrete. The walls of the building, above grade, were composed of 8inch concrete block. Inside the building was a $60 \mathrm{ft}$ liquid sodium storage tank on a reinforced concrete pedestal. The roof was composed of metal decking and 1-inch rigid insulation.

\section{$2.8 \quad 3718 P$ GENERAL STORAGE BUILDING}

The 3718-P Building was known as the General Storage Building, which supported D4 activities in the 300 Area. The 3718-P Building was located on Locust Street in the east side of the 300 Area. WCH took possession of the building in September 2007.

Figure 8. 3718P General Storage Building

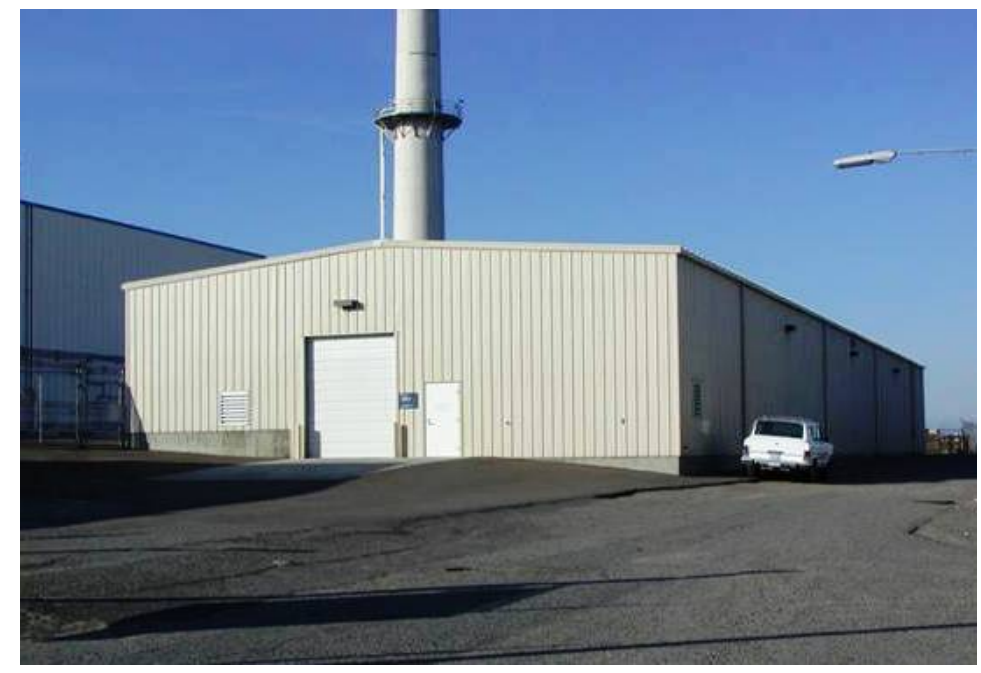


Constructed in 1996, the 3718-P Building was a single-story, rectangular facility constructed of a bolted steel framework structure on a concrete foundation with a gable type metal roof. The structure was $60 \mathrm{ft}$ by $196 \mathrm{ft}$ and had a total area of $11,760 \mathrm{ft}^{2}$. The building had a small room in the northwest corner which was used as an office area.

\subsection{SODIUM AND ACID STORAGE BUILDING}

The 3723 Building was located adjacent to the 327 Post-Irradiation Test Facility and was used to store acids and solvents. The building was also used as a storage location by waste management and recycling operations (i.e., storage location for spent batteries, etc.).

Figure 9. 3723 Sodium and Acid Storage Building

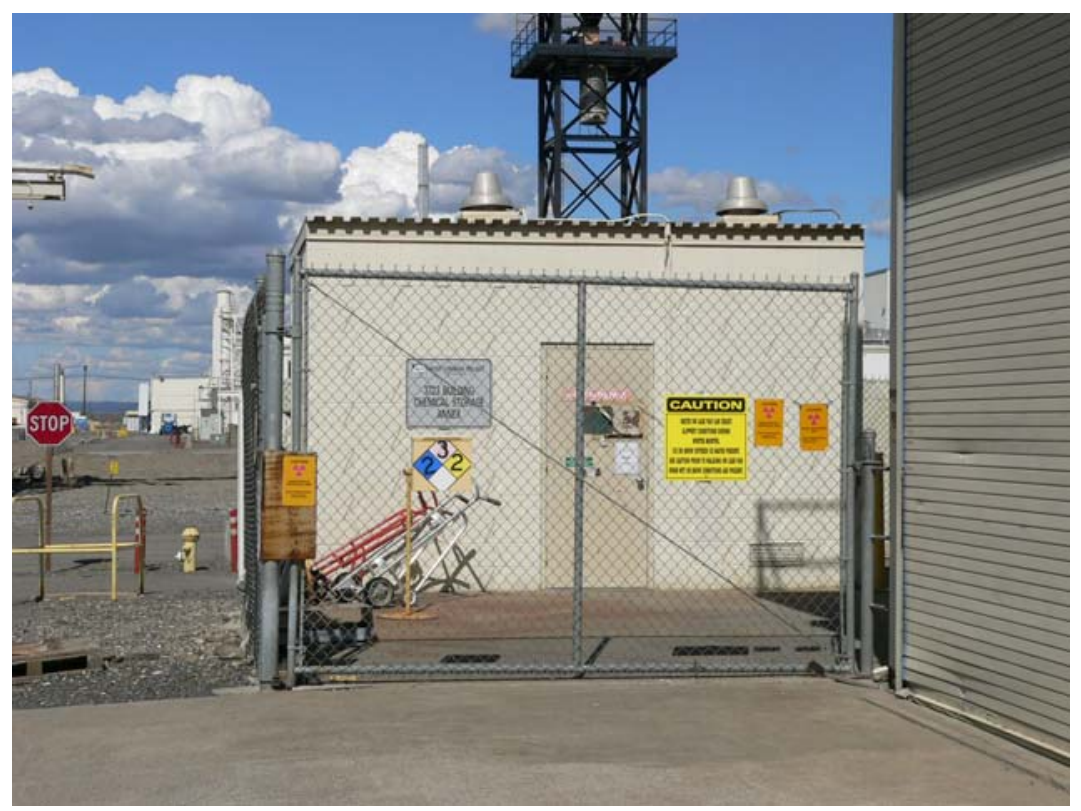

The 3723 Building was constructed of concrete block walls with a steel deck roof and a slab concrete floor. The size of the building was $144 \mathrm{ft}^{2}$. WCH took possession of the building in August 2005.

\subsection{MO-274 MOBILE OFFICE}

The MO-274 mobile office trailer was brought onto the Hanford site in 1993 and was located in the south central region of the 300 Area. The trailer was used by the Industrial Hygiene group as a temporary office space, meeting room, and lunch area. One room (Room 9) in the trailer was used as a Fiber Counting Room for counting and storing asbestos air samples (some samples were radiological). This room was posted as a Radiologically Controlled Area (RCA).

The mobile office trailer was a double-wide, $28 \mathrm{ft}$ by $66 \mathrm{ft}$, transportable metal clad building on a steel frame. The exterior under portion of the trailer was covered with metal under-skirting material. 
Figure 10. MO-274 Mobile Office

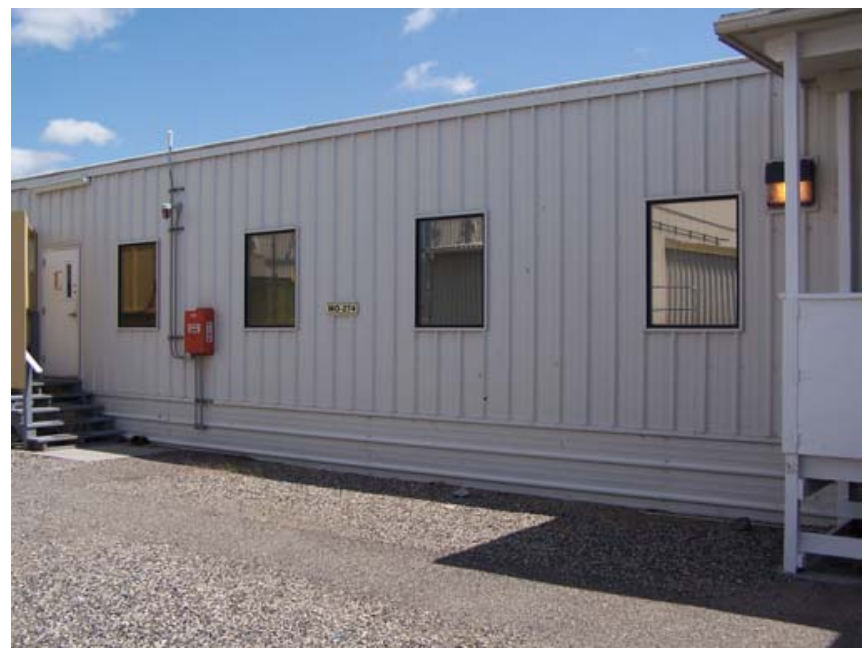

\subsection{MO-275 MOBILE BUILDING}

The MO-275 mobile office trailer was brought onto the Hanford site in 1993 and was located in the south central region of the 300 Area. The trailer was used by senior management and project controls personnel as a temporary office space, meeting room, and lunch area.

The mobile office trailer was a double-wide, $28 \mathrm{ft}$ by $66 \mathrm{ft}$, transportable metal clad building on a steel frame. The exterior under portion of the trailer was covered with metal under-skirting material.

Figure 11. MO-275 Mobile Office

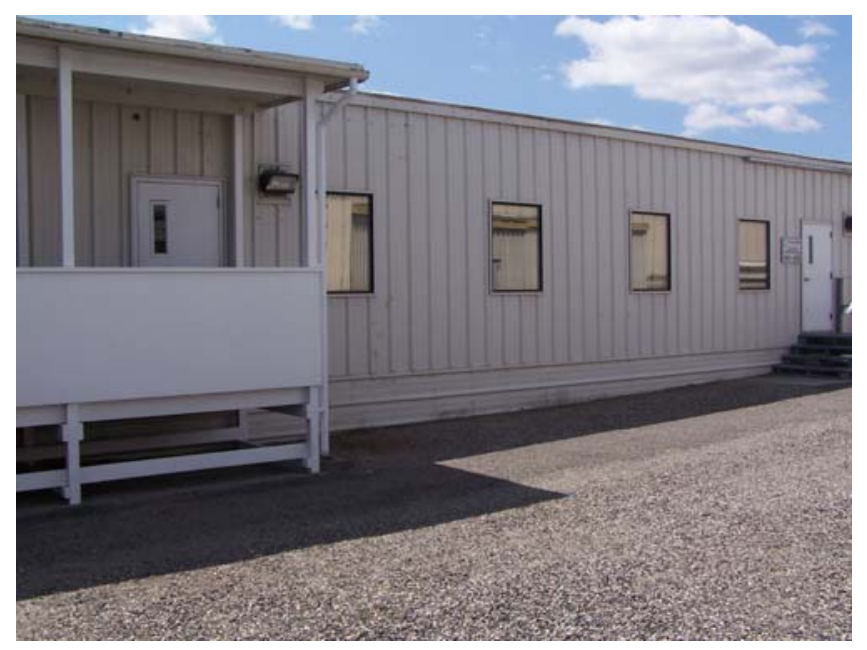




\subsection{PROJECT ACTIVITIES}

\subsection{ENGINEERING AND PERMITS}

The Removal Action Work Plan for 300 Area Facilities (DOE-RL, 2007) was prepared to satisfy the requirements of the action memoranda \#1, \#2 and \#3 (EPA and DOE 2005; 2006a; 2006b), outlining how compliance with, and enforcement of, applicable regulations will be achieved for cleanup of 300 Area facilities. Additionally, the removal action work plan (DOE-RL 2007) and environmental control plan $(\mathrm{WCH}, 2009)$ serve as the decommissioning plan and project management plan for the 300 Area project. The removal action work plan was prepared in accordance with Section 7.2.4 of the Hanford Federal Facility Agreement and Consent Order (Tri-Party Agreement) (Ecology et al. 1989) and was approved by the DOE, Richland Operations Office and the United States Environmental Protection Agency.

Plant Forces Work Reviews were prepared for the demolition of the facilities to determine whether Davis-Bacon Act of 1931 prevailing wage rates for the work were applicable. Table 1 summarizes the reviews performed. The D4 work on all buildings was determined to be "not applicable" and the work was performed by plant forces.

Table 1. Plant Forces Work Reviews.

\begin{tabular}{|l|c|l|}
\hline \multicolumn{1}{|c|}{ Building } & PFWR Number & \multicolumn{1}{|c|}{ PFWR Title } \\
\hline 3718M, 3718P & $8850-059-06$, Rev. 1 & $\begin{array}{l}\text { Demolition of Various 300 Area } \\
\text { Buildings }\end{array}$ \\
\hline $\begin{array}{l}\text { 315, 315A, 315B, 324, 327, 336, } \\
\text { 338, 3723, MO-274, MO-275 }\end{array}$ & $8850-027-07$, Rev. 1 & Demolition of 300 Area Buildings \\
\hline 384 & $8850-022-06$, Rev. 1 & Demolition of 384 Powerhouse \\
\hline
\end{tabular}

Criticality screenings for the facilities were performed where required. These criticality evaluations showed that fissionable material inventories did not exceed threshold activity values and no criticality safety requirements or controls were needed for the buildings. In addition, all the facilities were either non-nuclear or categorized as below Category 3 based on DOE Standard - Hazard Categorization and Accident Analysis Techniques for Compliance with DOE Order 5480.23, Nuclear Safety Analysis Reports (DOE-STD-1027-92, Change Notice No. 1 [DOE 1997]). Table 2 identifies the facilities and associated hazard categorization documents for each.

Table 2. Hazard Categorization Evaluations and Results.

\begin{tabular}{|l|l|l|}
\hline \multicolumn{1}{|c|}{ Facility } & \multicolumn{1}{|c|}{ IHC/FHC Number } & \multicolumn{1}{|c|}{ IHC/FHC Category } \\
\hline 324 Building Support Area & Addendum WCH-282, Rev. 0 & $\begin{array}{l}\text { Part of a Below } \\
\text { Category 2 Facility }\end{array}$ \\
\hline 327,3723 & FHC WCH-232, Rev. 0 & Below Category 3 \\
\hline $\begin{array}{l}\text { 315, 315A, 315B, 336, 338, 384, 3718M, } \\
\text { 3718P, MO-274, MO-275 }\end{array}$ & IHC-2006-0017, Rev. 2 & Non-Nuclear \\
\hline
\end{tabular}

$\mathrm{IHC}=$ Initial Hazard Categorization FHC = Final Hazard Categorization

The quantity of nonradioactive hazardous substances did not exceed the threshold quantities ("Threshold Quantities" as defined in 20 Code of Federal Regulations 1910.119 or 40 CFR 68.130). 


\subsection{HAZARDOUS MATERIAL REMOVAL}

The scope of the demolition project included removing and properly disposing of hazardous materials (e.g., oils, grease, asbestos-containing material, mercury, lead, and PCBs). All known hazardous materials were removed from inside and outside of the buildings to the extent practical prior to demolition. Some hazardous materials may have remained in the buildings during demolition (e.g., lead shielding embedded in concrete). In most cases, some Class II non-friable asbestos containing material (e.g., roofing material, floor tile, and vinyl sheeting) was left in place and removed during the demolition phase of the project. In these cases, all building demolition waste was treated as asbestos waste, and controls to minimize asbestos fiber release (e.g., fixatives, wet methods, and air monitoring) were used throughout the demolition process.

Beryllium-contaminated equipment, including high-efficiency particulate air filters and duct work, were of particular concern in those buildings that were beryllium listed. These items were thoroughly characterized prior to removal, and work control methods to minimize airborne beryllium particulate (e.g., fixatives, wet methods, air monitoring, and hygiene practices) were implemented throughout the decommissioning and demolition process.

\subsection{RADIOLOGICAL CONTAMINATION STABILIZATION}

If warranted, a radiological characterization/scoping survey was performed prior to demolition. Any loose/residual contamination on building surfaces, in/on piping and ducting, and in/on equipment would be fixed in place to prevent the spread of contamination.

\subsection{UTILITY AND DRAIN ISOLATION}

Once the utilities were no longer needed in the building (prior to hazardous materials removal), all electrical, water, and telecommunications services were disconnected from the buildings. Floor drains were sealed to provide isolation. Sanitary sewers to the building were disconnected during early deactivation activities and all drains were grouted.

\subsection{DEMOLITION OF ABOVE-GRADE STRUCTURES}

In general, after the hazardous materials and equipment removal activities were performed and utilities isolated, the above-grade structures were ready for demolition. The building structures were demolished using excavator-mounted hydraulic shears and a bucket-and-thumb. The debris was segregated for loading and disposal. Standard Environmental Restoration Disposal Facility (ERDF) roll-on/roll-off containers with two 6-mil liners were used to package and ship debris. 


\subsection{BELOW-GRADE DEMOLITION AND SITE RESTORATION}

In general, for each building demolished (or for a given complex) a post-demolition summary report (PDSR) is prepared that documents the characterization and final status of the building at the completion of the D4 activities. Table 3 summarizes the as-left conditions of each facility. Slabs left in place will be removed at a later date by either the D4 Closure Project or the Field Remediation Closure Project. Also summarized in Table 3 is the current site posting for each facility.

Table 3. Facility As-Left Condition Summary.

\begin{tabular}{|c|l|l|}
\hline Building & \multicolumn{1}{|c|}{ Slab/Below-Grade Condition } & \multicolumn{1}{|c|}{ Site Posting } \\
\hline $315,315 \mathrm{~A}, 315 \mathrm{~B}$ & $\begin{array}{l}\text { Clear well and below-grade slab } \\
\text { remain. }\end{array}$ & None \\
\hline 327 & $\begin{array}{l}\text { Basement remains with dry } \\
\text { carousel, lower SERF, and RLWS } \\
\text { piping remaining. The FHC covers } \\
\text { the continued 327 work. }\end{array}$ & Radioactive Contamination Area \\
\hline 336 & $\begin{array}{l}\text { Controlled Density Fill (CDF) filled } \\
\text { caisson and slab remain. }\end{array}$ & Fall Hazard Barrier \\
\hline 338 & Basement and slab remain. & Fall Hazard Barrier \\
\hline 384 & Basement slab remains. & Open Excavation \\
\hline $3718 \mathrm{M}$ & $\begin{array}{l}\text { Tank vault slab and portion of } \\
\text { north, below-grade wall remain. }\end{array}$ & Fall Hazard Barrier \\
\hline $3718 \mathrm{P}$ & $\begin{array}{l}\text { Slab and decommissioned well } \\
\text { remain. }\end{array}$ & None \\
\hline 3723 & Slab removed. & Radioactive Contamination Area \\
\hline MO-274 Trailer & Not Applicable & None \\
\hline MO-275 Trailer & Not Applicable & None \\
\hline $\begin{array}{c}324 \text { Building Support } \\
\text { Area }\end{array}$ & Slabs remain. & None \\
\hline
\end{tabular}




\subsection{COST AND SCHEDULE}

The following section details start and finish dates for the major D4 activities in each of the facilities as well as the total labor costs. These costs do not include deactivation or surveillance and maintenance work performed by Fluor Hanford, Bechtel Hanford, Inc., and other contractors prior to turnover of the building to $\mathrm{WCH}$. They also do not include overhead or distributed costs, equipment and material costs, or incidental work performed by subcontractors.

Note that some activities began prior to the current reporting year, but the demolition occurred in FY2010. Entries reading "NC" mean that no costs were collected or charged specifically to this activity. Also note that the 324 Building Support Areas (new office addition, High-Bay Engineering Laboratory, maintenance shop, and 324C Experimental Lithium Enclosure) were demolished in FY09 and FY10, but the cost figures were not broken out separately. The costs associated with these buildings will be included in the total cost of the 324 Complex D4 activities and are therefore not included in this cost summary.

The total labor cost (before overhead and distributed costs) for all buildings was $\$ 21,434,892$.

Table 4. Cost and Schedule Summary. (3 Pages)

\begin{tabular}{|l|c|c|r|}
\hline 315 Building & Start Date & Completion Date & \multicolumn{1}{c|}{ Cost } \\
\hline Engineering Planning & $01 / 26 / 09$ & $08 / 20 / 09$ & $\$ 14,541$ \\
\hline Building Deactivation & $03 / 01 / 10$ & $06 / 17 / 10$ & $\$ 36,154$ \\
\hline Building Demolition (AG) & $06 / 22 / 10$ & $08 / 10 / 10$ & $\$ 40,541$ \\
\hline Waste Loadout & $07 / 12 / 10$ & $08 / 18 / 10$ & TOTAL \$115,860 \\
\hline \multicolumn{3}{|r|}{}
\end{tabular}

\begin{tabular}{|l|c|c|r|}
\hline 315A Building & Start Date & Completion Date & Cost \\
\hline Engineering Planning & $01 / 26 / 09$ & $08 / 20 / 09$ & NC \\
\hline Building Deactivation & $03 / 01 / 10$ & $06 / 17 / 10$ & $\$ 1,003$ \\
\hline Building Demolition & $06 / 22 / 10$ & $08 / 10 / 10$ & $\$ 1,044$ \\
\hline Waste Loadout & $07 / 12 / 10$ & $08 / 18 / 10$ & TOTAL \$2,567 \\
\hline \multicolumn{3}{|r|}{}
\end{tabular}

\begin{tabular}{|l|c|c|r|}
\hline 315B Building & Start Date & Completion Date & Cost \\
\hline Engineering Planning & $01 / 26 / 09$ & $08 / 20 / 09$ & NC \\
\hline Building Deactivation & $03 / 01 / 10$ & $06 / 17 / 10$ & NC \\
\hline Building Demolition & $06 / 22 / 10$ & $08 / 10 / 10$ & T1,120 \\
\hline Waste Loadout & $07 / 12 / 10$ & $08 / 18 / 10$ & TOTAL \$1,813 \\
\hline \multicolumn{3}{|r|}{}
\end{tabular}

\begin{tabular}{|l|c|c|r|}
\hline 327 Building & Start Date & Completion Date & \multicolumn{1}{|c|}{ Cost } \\
\hline Engineering Planning & $08 / 29 / 05$ & $09 / 28 / 06$ & $\$ 91,275$ \\
\hline Building Deactivation & $10 / 03 / 05$ & $08 / 26 / 10$ & $\$ 9,223,965$ \\
\hline Building Demolition (AG) & $04 / 01 / 09$ & $09 / 29 / 10$ & $\$ 10,560,432$ \\
\hline Waste Loadout & $06 / 07 / 10$ & $09 / 29 / 10$ & TOTAL\$19,970,046 \\
\hline \multicolumn{3}{|r|}{}
\end{tabular}




\begin{tabular}{|l|c|c|r|}
\hline 336 Building & Start Date & Completion Date & \multicolumn{1}{|c|}{ Cost } \\
\hline Engineering Planning & $10 / 01 / 08$ & $03 / 04 / 10$ & $\$ 36,149$ \\
\hline Building Deactivation & $04 / 27 / 09$ & $06 / 17 / 09$ & $\$ 131,051$ \\
\hline Building Demolition (AG) & $12 / 21 / 09$ & $03 / 18 / 10$ & $\$ 49,768$ \\
\hline Waste Loadout & $03 / 08 / 10$ & $03 / 31 / 10$ & $\$ 12,606$ \\
\hline
\end{tabular}

TOTAL \$229,574

\begin{tabular}{|l|c|c|r|}
\hline 338 Building & Start Date & Completion Date & \multicolumn{1}{|c|}{ Cost } \\
\hline Engineering Planning & $10 / 13 / 08$ & $07 / 23 / 09$ & $\$ 32,211$ \\
\hline Building Deactivation & $03 / 30 / 09$ & $04 / 30 / 09$ & $\$ 78,488$ \\
\hline Building Demolition (AG) & $07 / 14 / 09$ & $04 / 14 / 10$ & $\$ 355,321$ \\
\hline Waste Loadout & $10 / 01 / 09$ & $05 / 1010$ & TOTAL \$519,557 \\
\hline \multicolumn{3}{|r|}{}
\end{tabular}

\begin{tabular}{|l|c|c|r|}
\hline 384 Building (BG) & Start Date & Completion Date & \multicolumn{1}{c|}{ Cost } \\
\hline Building Demolition (BG) & $4 / 6 / 09$ & $11 / 10 / 09$ & $\$ 16,552$ \\
\hline Waste Loadout (BG) & $4 / 15 / 09$ & $11 / 19 / 09$ & TOTAL $\$ 55,137$ \\
\hline \multicolumn{3}{|r|}{}
\end{tabular}

\begin{tabular}{|l|c|c|r|}
\hline 3718M Building & Start Date & Completion Date & \multicolumn{1}{c|}{ Cost } \\
\hline Engineering Planning & $02 / 12 / 07$ & $06 / 2909$ & $\$ 14,210$ \\
\hline Building Deactivation & $04 / 19 / 10$ & $08 / 18 / 10$ & $\$ 293,832$ \\
\hline Building Demolition (BG) & $05 / 28 / 09$ & $08 / 23 / 10$ & $\$ 143,637$ \\
\hline Waste Loadout & $06 / 15 / 09$ & $10 / 07 / 10$ & TOTAL \$480,661 \\
\hline
\end{tabular}

\begin{tabular}{|l|c|c|r|}
\hline 3718P Building & Start Date & Completion Date & \multicolumn{1}{|c|}{ Cost } \\
\hline Engineering Planning & $11 / 30 / 09$ & $07 / 01 / 10$ & $\$ 3,820$ \\
\hline Building Deactivation & $12 / 09 / 09$ & $12 / 17 / 09$ & $\$ 5,397$ \\
\hline Building Demolition (AG) & $12 / 21 / 09$ & $12 / 29 / 09$ & $\$ 15,752$ \\
\hline Waste Loadout & $12 / 22 / 09$ & $07 / 01 / 10$ & TOTAL \$32,830 \\
\hline
\end{tabular}

\begin{tabular}{|l|c|c|r|}
\hline 3723 Building & Start Date & Completion Date & Cost \\
\hline Engineering Planning & $08 / 30 / 10$ & $08 / 31 / 10$ & NC \\
\hline Building Deactivation & $08 / 30 / 10$ & $08 / 31 / 10$ & NC \\
\hline Building Demolition (AG) & $09 / 01 / 10$ & $09 / 02 / 10$ & NC \\
\hline Waste Loadout & \multicolumn{3}{|c|}{ TOTAL \$NC (cost included with 327 Building) } \\
\hline
\end{tabular}

\begin{tabular}{|l|c|c|r|}
\hline MO-274 Building & Start Date & Completion Date & \multicolumn{2}{|c|}{ Cost } \\
\hline Engineering Planning & $06 / 29 / 09$ & $10 / 07 / 09$ & $\$ 365$ \\
\hline Building Deactivation & $09 / 30 / 09$ & $10 / 15 / 09$ & $\$ 1,016$ \\
\hline Building Demolition & $10 / 19 / 09$ & $10 / 22 / 09$ & $\$ 8,743$ \\
\hline Waste Loadout & $10 / 28 / 09$ & $11 / 10 / 09$ & $\$ 4,764$ \\
\hline
\end{tabular}


TOTAL\$14,888

\begin{tabular}{|l|c|c|r|}
\hline MO-275 Building & Start Date & Completion Date & Cost \\
\hline Engineering Planning & $06 / 29 / 09$ & $10 / 07 / 09$ & $\$ 365$ \\
\hline Building Deactivation & $09 / 30 / 09$ & $10 / 15 / 09$ & $\$ 833$ \\
\hline Building Demolition & $10 / 19 / 09$ & $10 / 22 / 09$ & $\$ 4,735$ \\
\hline Waste Loadout & $10 / 28 / 09$ & $11 / 10 / 09$ & TOTAL\$11,407 \\
\hline
\end{tabular}

GRAND TOTAL $\$ 21,434,892$

AG - Above Grade Demolition

BG - Below Grade Demolition

NC - No costs collected or charged specifically to this activity 


\subsection{WASTE DISPOSITION}

One of the objectives of the 300 Area D4 Project is to support recycling and waste minimization. However, beryllium and radiological contamination throughout the site prevents most of the material and equipment from being salvaged and/or transferred offsite. All of the debris for buildings identified in this report was shipped to the ERDF for disposal.

Waste generated from demolition of the buildings, and from the demolition of other below-grade structures removed in FY2010, was characterized under waste profiles and shipped to ERDF. Roll-on/roll-off boxes were used to ship the debris. The total number of these shipments ("cans"), tons of debris disposed of in ERDF, and the profiles used are listed in below.

Table 5. Waste Transferred to ERDF.

\begin{tabular}{|c|c|c|c|}
\hline Facility & $\begin{array}{l}\text { Number of } \\
\text { Shipments }\end{array}$ & Tons & Waste Profile(s) \\
\hline $315,315 A, 315 B$ & 119 & 1793 & WP300LSF001 \\
\hline 324 Support Areas & 233 & 2089 & WP324001, 002 \\
\hline 327,3723 & 193 & 1286 & WP327001 \\
\hline 336 & 74 & 501 & WP300FDT001 \\
\hline 338 & 112 & 952 & WP300FDT001 \\
\hline $3718 \mathrm{P}$ & 25 & 78 & WP300LSF001 \\
\hline MO-274, MO-275 & 41 & 184 & WP300LSF001 \\
\hline $\begin{array}{c}\text { On/Below Grade } \\
\text { (FY Above-Grade } \\
\text { Removed) }\end{array}$ & $\begin{array}{l}\text { Number of } \\
\text { Shipments }\end{array}$ & Tons & Waste Profile (s) \\
\hline 313 (FY04) & 1840 & 36,258 & WP300SLABS001 \\
\hline 314 (FY06) & 610 & 12,020 & WP300SLABS001 \\
\hline 333 (FY06) & 62 & 1176 & WP300SLABS001 \\
\hline 303 (FY06) & 23 & 416 & WP300SLABS001 \\
\hline 303J (FY06) & 90 & 1930 & WP3006001 \\
\hline $384^{(1)}(\mathrm{FY} 10)$ & 163 & 2630 & WP300UFPSB001, 002, 003 \\
\hline 3720 (FY07) & 48 & 932 & WP300SLABS001 \\
\hline 3712 (FY06) & 229 & 4417 & WP300SLABS001 \\
\hline 3715 (FY06) & 31 & 631 & WP3006001 \\
\hline 3707D (FY06) & 120 & 2421 & WP300SLABS001 \\
\hline $3718 \mathrm{M}^{(2)}(\mathrm{N} / \mathrm{A})$ & 9 & 19 & WP300LSF001 \\
\hline
\end{tabular}

Notes: (1) Basement slab remains. (2) Tank vault slab and portion of north, below-grade wall remain. 


\subsection{OCCUPATIONAL EXPOSURES}

\subsection{PERSONNEL INJURIES}

Washington Closure Hanford D4 Project personnel worked a total of approximately 97,000 hours (manual and non-manual, including subcontractors) on the D4 of the buildings in the 300 Area in FY2010 with 1 Occupational Safety and Health Administration recordable injury and 0 lost workday cases.

\subsection{PERSONNEL RADIOLOGICAL EXPOSURES}

Of the eleven 300 Area facilities discussed in this report, four (4) clothing and zero (0) skin contamination incidents occurred and 2,671 person-mrem was received during D4. All incidents and dose received were in the 327 facility. All boundary air sample results were below procedural action levels for the duration of the project. 


\subsection{REFERENCES}

20 CFR 1910, "Occupational Safety and Health Standards," Code of Federal Regulations, as amended.

40 CFR 68, "Chemical Accident Prevention Provisions," Code of Federal Regulations, as amended.

Davis-Bacon Act of 1931, 40 U.S.C. $276 a$, et seq.

DOE, 1997, DOE Standard - Hazard Categorization and Accident Analysis Techniques for Compliance with DOE Order 5480.23, Nuclear Safety Analysis Reports, DOE-STD-1027-92, Change Notice No. 1, U.S. Department of Energy, Washington, D.C.

DOE-RL, 2007, Removal Action Work Plan for 300 Area Facilities, DOE/RL-2004-77, Rev. 2, U.S. Department of Energy, Richland Operations Office, Richland, Washington.

Ecology, EPA, and DOE, 1989, Hanford Federal Facility Agreement and Consent Order, 2 vols., as amended, Washington State Department of Ecology, U.S. Environmental Protection Agency, and U.S. Department of Energy, Olympia, Washington.

EPA and DOE, 2005, Action Memorandum \#1 for the 300 Area Facilities, CCN 118781, U.S. Environmental Protection Agency and U.S. Department of Energy, Richland Operations Office, Richland, Washington.

EPA and DOE, 2006a, Action Memorandum \#2 for the 300 Area Facilities, CCN 127831, U.S. Environmental Protection Agency and U.S. Department of Energy, Richland Operations Office, Richland, Washington.

EPA and DOE, 2006b, Action Memorandum \#3 for the 300 Area Facilities, CCN 131082, U.S. Environmental Protection Agency and U.S. Department of Energy, Richland Operations Office, Richland, Washington.

WCH, 2009, 300 Area Facilities D4 Environmental Control Plan, WCH-84, Rev. 1, Washington Closure Hanford, Richland, Washington. 


\section{DISTRIBUTION}

U.S. Department of Energy

Richland Operations Office

R. F. Guercia

A3-04

Washington Closure Hanford

K. J. Koegler

L7-11

L. M. Douglas

L7-10

D. A. Elkins

L4-31

D. J. McBride

L7-11

B. D. Smith

L7-11

G. B. Snow

L7-11

C. P. Strand

L7-10

Document Control

$\mathrm{H} 4-11$

DOE-RL Public Reading Room

$\mathrm{H} 2-53$

Hanford Technical Library

P8-55 